\title{
Review
}

\section{Why democracy is oppositional}

\author{
John Medearis \\ Harvard University Press, Cambridge, MA, 2015, 257pp., \\ ISBN: 978-0-674-72533-1
}

Contemporary Political Theory (2018) 17, S70-S73. https://doi.org/10.1057/s41296017-0113-3; published online 18 April 2017

As a way of challenging the most prevalent modes of democratic thinking, John Medearis's Why Democracy Is Oppositional expands the analysis of democracy beyond its ordinary domains. The book argues that, in thinking of democracy primarily as a form of government, or as an ideal mode of discourse among citizens, we risk overlooking the wide variety of threats to-and resources for-the achievement of 'collective, egalitarian management of the institutions and forces that shape our lives' (p. 2). Medearis asks us to see democracy primarily as a matter of continuous oppositional exertion, which covers the need to oppose both those powerful individuals who benefit from undemocratic management of crucial institutions and forces, and those qualities in ourselves that end up unintentionally reinforcing these undemocratic situations. Medearis seeks to expose the 'elite' and 'deliberative' theories of democracy for overly simplifying both the obstacles to democracy and the methods by which we can further achieve democracy. In this task, his book is, in my judgment, quite successful. Medearis also helps illuminate new paths on which democratic theory can travel in order to better understand the challenge of democratizing not only our politics, but our society more broadly.

The book's critique of elite and deliberative theory is rooted primarily in the claim that these theories neglect the democratic significance of social movements, and adhere to an unproductive ideal/non-ideal binary. Deliberative theory restricts democracy to a controlled setting in order to create an ideal interaction among citizens. This leads its proponents to diminish the importance of what takes place outside that setting and to focus critique on individuals' behavior, obscuring broad social forces. Elite theory, by contrast, takes the non-ideal route of presuming that ordinary citizens' apparent incapacity for meaningful political participation is irremediable; it thus aims to leave elected leaders unencumbered to make political decisions, and has scant interest in social movements, through which less-powerful individuals might intrude on the territory of the more powerful. Medearis claims that a focus on social movements is necessary for understanding why their efforts have in fact been historically so crucial to the further achievement of democracy. He also

(C) 2017 Macmillan Publishers Ltd. 1470-8914 Contemporary Political Theory Vol. 17, S2, S70-S73 
holds that a focus on movements helps us transcend the ideal/non-ideal binary, for these movements represent a way of actualizing a democratic ideal in the face of a non-ideal present-rather than limiting democracy only to an ideal 'deliberative' setting, or treating the non-ideal present as simply irremediable (p. 51).

To build an alternative vision, Medearis points to Karl Marx and John Dewey as resources for conceptualizing democracy as continuous exertion in response to social forces and institutions that have escaped democratic control-or, what Medearis calls the 'alienation' of social forces and institutions (p. 54). Marx and Dewey are not preoccupied with an ideal conception of 'perfect democratic relations.' Instead they focus on present forms of alienation and what to do about them (p. 81). For Medearis, the task of opposing alienation is highly complex, since social forces and institutions become alienated not only because their undemocratic control allows powerful individuals to oppress and exploit the less powerful, but also because these forces and institutions are often reproduced and strengthened by the common activities of the less powerful. Market forces and institutions in particular have tended to become alienated, both because powerful individuals can benefit from the lack of democratic management of the market, and because the everyday economic behavior of ordinary people (e.g., buying products made by workers under horrible conditions in Bangladesh or China) can help reproduce these market forces and institutions (pp. 125-126).

Medearis's notion of 'oppositional democracy' affirms that democratic action must continually oppose new, emerging forms of alienation, and that it must avoid the belief in the possibility of a total transcendence of alienation. He also explains that oppositional democracy does not simply equate democracy with social movements-as opposed to practices like deliberation or voting-but that movements do merit particular attention. This is because they are both a means for changing a non-ideal present, and an end in themselves, i.e., they can manifest the self-governing capacities of individuals who are often oppressed and exploited by the more powerful (pp. 146-147). To substantiate the claim that democracy is defined by continuous opposition to new forms of alienation, Medearis provides multiple examples of institutions that may not be typically seen as threats to democracy, but that, he argues, have become alienated. For example, he explores how the institution of the welfare state has tended to escape democratic control and has left individuals vulnerable to oppression and exploitation. He shows how this has played out along racial and gender lines, with welfare states often placing women and members of disfavored racial groups in the most stigmatized, regulated, and punitive programs' (p. 186), further buttressing hierarchical racial and gender relations. Another important example of an alienated institution is the contemporary security state, a unique example due to the apparent high degree of separation between most ordinary citizens' lives and the state's surveillance and military activity. These state activities seem to be completely beyond the experience, and outside the comprehension, of most citizens. Medearis thus points

(c) 2017 Macmillan Publishers Ltd. 1470-8914 Contemporary Political Theory Vol. 17, S2, S70-S73 S71 
out that, because the consequences of combat and surveillance feel so remote, there may be no effective public that could organize to democratically manage these activities (pp. 204-206).

There is little that I have to criticize in this book. Medearis is, in my view, insightfully identifying problems that apply to a variety of current modes of democratic theorizing, and helping reorient democratic theory in useful new directions. Elite and deliberative theory, of course, appear radically opposed to one another, but Medearis diagnoses their similar inability to account for the democratic significance of social movements, as well as their similar attempt to focus the analysis of democracy on moments of political decision-making. There is indeed, I would say, an unfortunate aspect of many of the debates within current democratic theory, in that theorists have tended to focus on how political debate and decision-making should take place. This tends to neglect the significance of unequal social relations, e.g., of individuals' experiences of subordination in the workplace, or their encounters with systemic racism. These forms of structural inequality can represent direct threats to democracy on their own, and can interfere with the democratic quality of the very spaces of political decision-making theorists have been focusing on. Medearis's conception of oppositional democracy places its attention on such experiences of social inequality, and thus leads democratic theory into new territory.

The main weakness of the book relates to Medearis's discussion of whether we can justify violent forms of direct action. He addresses violence rather briefly, and rejects violence because 'action that attacks the needed conditions of [democratic] collective management should be considered out of bounds' (p. 148). This issue deserves a more extensive discussion, since it seems to me that judging violence to be out of bounds might depend on the degree of physical and/or psychological violence already being perpetrated by the oppressors against the oppressed. Malcolm X's (2013 [1964], pp. 321-322) famous advocacy of violence when African-Americans are denied basic rights by the U.S. government, and are violently attacked by police departments, could be especially useful to consider here. It is noteworthy that Dewey (who is again a major figure in Medearis's construction of 'oppositional democracy') does consider violence to be highly problematic in both moral and practical ways. However, Dewey also recognizes how violence can be bred by institutions that do not allow democratic change to take place in any orderly and peaceful way (Dewey 1954 [1927], p. 34). Even if we (like Dewey) do not expect that violence can reliably produce democratic change, we still must consider whether situations of oppression may reach a stage where violence can become a way to show effective resistance to the oppression. A fuller discussion of this question would have been welcome in Medearis's book. This is, nonetheless, a minor criticism of what is overall an extremely effective work on democracy.

Ultimately Why Democracy Is Oppositional represents a highly significant intervention into contemporary democratic theory. The book helps expose some 
important shortcomings in a variety of current modes of democratic thought, and makes a convincing case for why democratic theory must account for the importance of social movements and overcome the ideal/non-ideal binary. Medearis has built a compelling argument that, in the future, it would be more productive for democracy to be seen as continuous opposition to undemocratic tendencies that arise within our politics and society, rather than as a form of government or a mode of discourse.

\section{References}

Dewey, J. (1954/1927) The Public and Its Problems. Chicago: Swallow Press.

Malcolm, X. (2013/1964) The Ballot or the Bullet. In: M. Marable and G. Felber (eds.) The Portable Malcolm X Reader. New York: Grove Press.

Jeff Jackson

University of Chicago, Chicago, IL 60637, USA jcjackson@uchicago.edu 